\title{
Acquired factor $V$ inhibitor in a patient with mantle cell lymphoma presenting with hematuria followed by thrombosis: a case report
}

This article was published in the following Dove Press journal:

International Medical Case Reports Journal

24 February 2014

Number of times this article has been viewed

\author{
Naif I AlJohani ${ }^{1,2}$ \\ John $\mathrm{H}$ Matthews ${ }^{2}$ \\ 'King Faisal specialist hospital \\ and research centre, Saudi Arabia; \\ ${ }^{2}$ Division of Hematology, Department \\ of Internal Medicine, Queen's \\ University, Kingston, Ontario, Canada
}

\begin{abstract}
Acquired factor $\mathrm{V}$ inhibitor is a rare hemostatic disorder that presents with hemorrhagic manifestations in the vast majority of patients. Factor V inhibitor may develop through a variety of mechanisms involving development of alloantibodies or autoantibodies specific to Factor V. Autoantibodies, in particular, have been reported in a number of conditions. In this report, we describe a case of acquired factor $\mathrm{V}$ inhibitor in a patient with mantle cell lymphoma who presented with hematuria. Seven weeks after diagnosis and successful management, the patient developed deep vein thrombosis in the right lower extremity. The patient's factor V levels were normalized, and the inhibitor was successfully eradicated using corticosteroids. Here, we discuss this rare disorder, its unusual manifestation, and provide a mini-review of the current literature regarding factor $\mathrm{V}$ inhibitors.
\end{abstract}

Keywords: acquired factor $\mathrm{V}$ inhibitor, blood coagulation disorders, factor $\mathrm{V}$ deficiency, acquired bleeding disorders

\section{Introduction}

Factor $\mathrm{V}$ is a coagulation protein that is present in blood plasma as a single-chain polypeptide (approximately $80 \%$ ) and in platelet alpha-granules (approximately $20 \%$ ). ${ }^{1}$ Factor $\mathrm{V}$ is cleaved after binding to activated platelets and serves as a cofactor for factor $\mathrm{Xa}$ in the prothrombinase complex. This complex forms on the platelet surface and has limited proteolytic activity, converting prothrombin to thrombin to aid in blood clotting. ${ }^{2,3}$ Acquired inhibitors to factor $\mathrm{V}$ were first reported in $1955^{2-4}$ and develop in extremely rare cases ( $0.09-0.29$ cases per million persons) via development of alloantibodies or autoantibodies against factor V. Patients with acquired factor V inhibitors generally present with hemorrhagic manifestations. Here, we report a unique case of acquired factor $\mathrm{V}$ inhibitor in a patient with mantle cell lymphoma presenting with hematuria followed by thrombosis. The patient responded successfully to treatment with corticosteroids.

\section{Case report}

A 64-year-old man initially presented to us with complaints of fatigue and joint discomfort for several months prior to December 2008. He denied experiencing any fever, night sweats, and weight loss, and did not notice any swelling, recurrent infection, easy bleeding, or bruising. Further, he did not have a family history of any hematological disorder. His past medical history included hernia repair, renal colic, gastroesophageal reflux, and osteoarthritis.
Division of Hematology, Department of Internal Medicine, Queen's University,

94 Stuart Street, Kingston,

Ontario K7L 3N6, Canada

$\mathrm{Tel}+|6| 35336803$

Fax +l 6135336855

Email dr.naif.alj@gmail.com 
Upon examination, one left axillary lymph node was swollen to approximately $1-2 \mathrm{~cm}$, and was firm and slightly tender. His spleen was palpable on inspiration, and Castell's sign was positive; however, his liver was not enlarged. A complete blood count showed normal platelet and hemoglobin levels of $206 \times 10^{-9} / \mathrm{L}$ and $155 \mathrm{~g} / \mathrm{L}$, respectively, but a high white blood cell count of $18 \times 10^{-9} / \mathrm{L}$. A leukocyte differential indicated the following: lymphocytes 10.3 ; neutrophils 6.75; monocytes 0.58 ; eosinophils 0.23 ; and basophils 0.05 . Peripheral blood flow cytometry revealed a CD19+, CD20 $\mathrm{CD}^{+}, \mathrm{CD} 23^{-}, \mathrm{CD} 10^{-}$clonal B-cell population. Additionally, $37 \%$ of gated lymphocytes were FMC7-positive. The proportion of this FMC7-positive population reduced to 17\% during a second flow analysis one month later, suggesting the possibility of mantle cell lymphoma or CD23-negative chronic lymphoid leukemia. Given that the patient was asymptomatic and showed no signs of bone marrow failure, a strategy of watchful waiting was implemented.

In August 2009, 8 months after his initial visit, the patient was admitted to the emergency room with a 2-day history of hematuria. Evaluation of his blood plasma revealed a prolonged international normalized ratio (INR) of 6 and an activated partial thromboplastin time of 160 seconds. Except for some minor skin bruising on his face, the patient had no other bleeding or bruising, nor was any area abnormal on examination. Further, he had no past history of bleeding, with uneventful surgical procedures and tooth extractions in the past. On careful investigation of his coagulopathy, a prothrombin time mixing study was abnormal at -43 partially corrected to 30 seconds only (normal $12.5-15.7$ seconds), suggesting the presence of an inhibitor. The thrombin time was 15.8 seconds (normal 15.5-18.3 seconds), serum fibrinogen level was $5.8 \mathrm{~g} / \mathrm{L}$ (normal $2.00-4.30 \mathrm{~g} / \mathrm{L}$ ), factor $\mathrm{V}$ level was $<0.01 \mathrm{U} / \mathrm{mL}$ (normal $0.5-1.5 \mathrm{U} / \mathrm{mL}$ ), factor VIII level was $3.23 \mathrm{U} / \mathrm{mL}$ (normal $0.5-1.5 \mathrm{U} / \mathrm{mL}$ ), factor $\mathrm{X}$ level was $1.08 \mathrm{U} / \mathrm{mL}$ (normal $0.5-1.5 \mathrm{U} / \mathrm{mL}$ ), and factor IX level was $1.17 \mathrm{U} / \mathrm{mL}$ (normal $0.5-1.5 \mathrm{U} / \mathrm{mL}$ ). Lupus anticoagulant testing could not be interpreted owing to the presence of the inhibitor. Serum protein electrophoresis did not indicate the presence of a monoclonal protein. Based on these results, a factor $\mathrm{V}$ inhibitor test was performed, and indicated a factor $\mathrm{V}$ inhibitor titer of 80 Bethesda units. The patient was started on prednisone ( $1 \mathrm{mg} / \mathrm{kg}, 80 \mathrm{mg}$ daily), and after 2 weeks of treatment, the bleeding had stopped and serial measurement of factor $\mathrm{V}$ levels showed a dramatic increase; moreover, within 7 weeks, factor $\mathrm{V}$ levels were normal and factor $\mathrm{V}$ inhibitor was undetectable.
Surprisingly, 7 weeks after initiation of steroid treatment, the patient developed an unprovoked severe pain with swelling in his right leg. A week prior to this event, his prothrombin time was 17 seconds, activated partial thromboplastin time was 28 seconds, INR was 1.4 , and the factor $\mathrm{V}$ assay value was 0.62 Bethesda units $/ \mathrm{mL}$, but factor $\mathrm{V}$ inhibitor was undetectable. Doppler ultrasound revealed deep venous thrombosis, and low-molecular-weight heparin (dalteparin, $12,500 \mathrm{U}$ ) and coumadin (7.5 mg) were administered orally once daily. The patient's condition continued to improve with no further bleeding or thrombotic events, and anticoagulation was successfully discontinued after 8 months. The use of prednisone was gradually decreased over several weeks after confirmation of the disappearance of the inhibitor, and was discontinued completely in December 2009 (Figure 1). Screening assays to rule out inherited thrombophilia were negative for antithrombin, protein $\mathrm{C}$, protein $\mathrm{S}$, factor $\mathrm{V}$ Leiden, and prothrombin 20210 gene mutations. Fluorescence in situ hybridization analysis of a peripheral blood sample showed IGH/CCND1 $t(11 ; 14)$, which confirmed the presence of a clonal B-cell population characteristic of mantle cell lymphoma.

\section{Discussion}

The clinical presentation of factor $\mathrm{V}$ inhibitors can range from asymptomatic hematological laboratory abnormalities to life-threatening hemorrhage. Factor $\mathrm{V}$ inhibitor has been associated with a number of conditions, including antibiotic use, sepsis, malignancies, ${ }^{10}$ autoimmune illnesses, vasculitis, valproic acid use, systemic amyloidosis, cold agglutinin disease, human immunodeficiency virus infection, hematopoietic stem cell transplantation, and liver transplantation, as well as use of amiodarone and warfarin., ${ }^{2,11-13}$

If bleeding occurs, it predominantly involves the mucous membranes of the gastrointestinal, airway, and urinary tracts. ${ }^{2}$ In contrast with other coagulation factor inhibitors, the level of factor $\mathrm{V}$ inhibitors does not correlate with the degree of clinical bleeding, and Streiff et al noted that patients who developed spontaneous factor $\mathrm{V}$ inhibitors had more significant bleeding than those with bovine thrombin-related factor $\mathrm{V}$ inhibitors. ${ }^{14} \mathrm{In}$ addition, the risk of bleeding does not seem to correlate with prolongation of prothrombin time or activated partial thromboplastin time, factor $\mathrm{V}$ activity, factor $\mathrm{V}$ inhibitor levels, or the duration of presence of factor $\mathrm{V}$ inhibitor. ${ }^{14}$

Because factor $\mathrm{V}$ is an anticoagulant, reports of thrombosis in patients with acquired factor $\mathrm{V}$ inhibitor are 


\section{A}
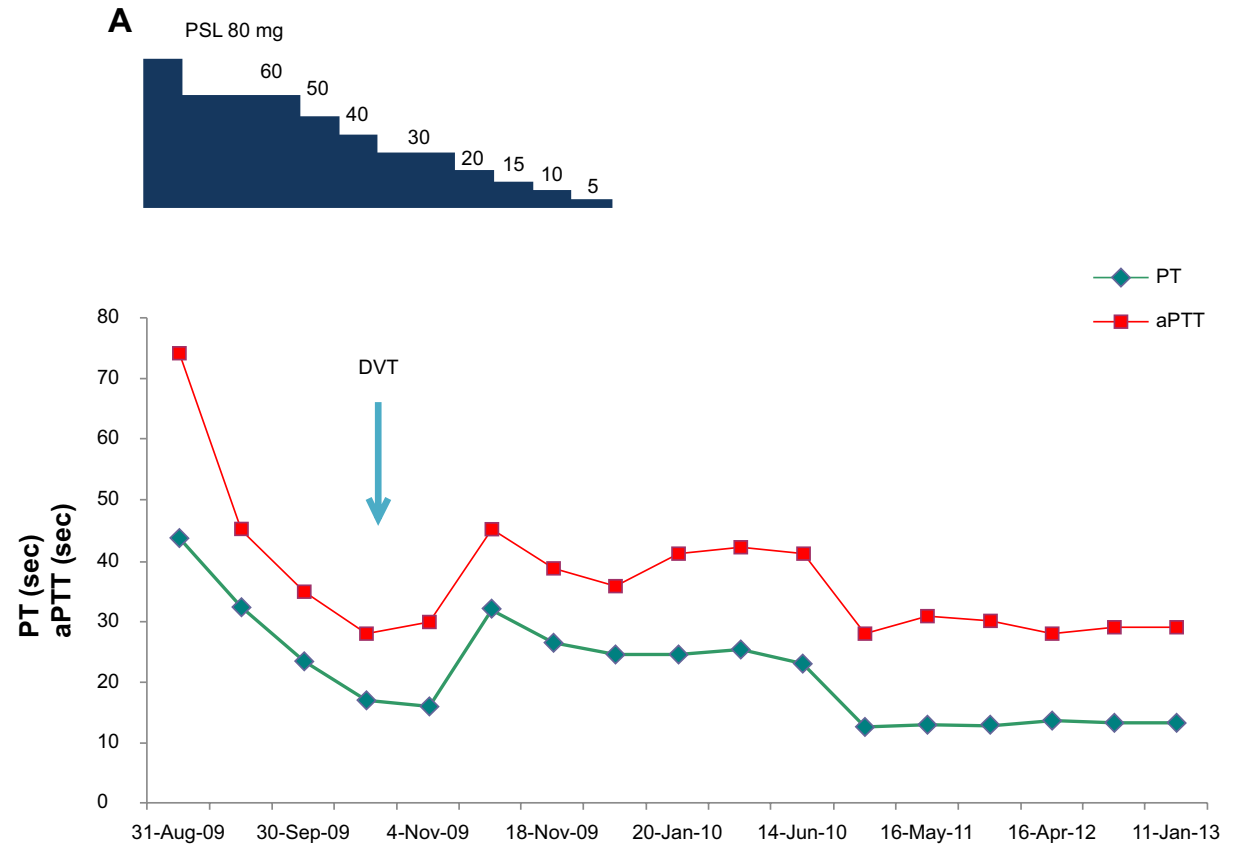

Date

B
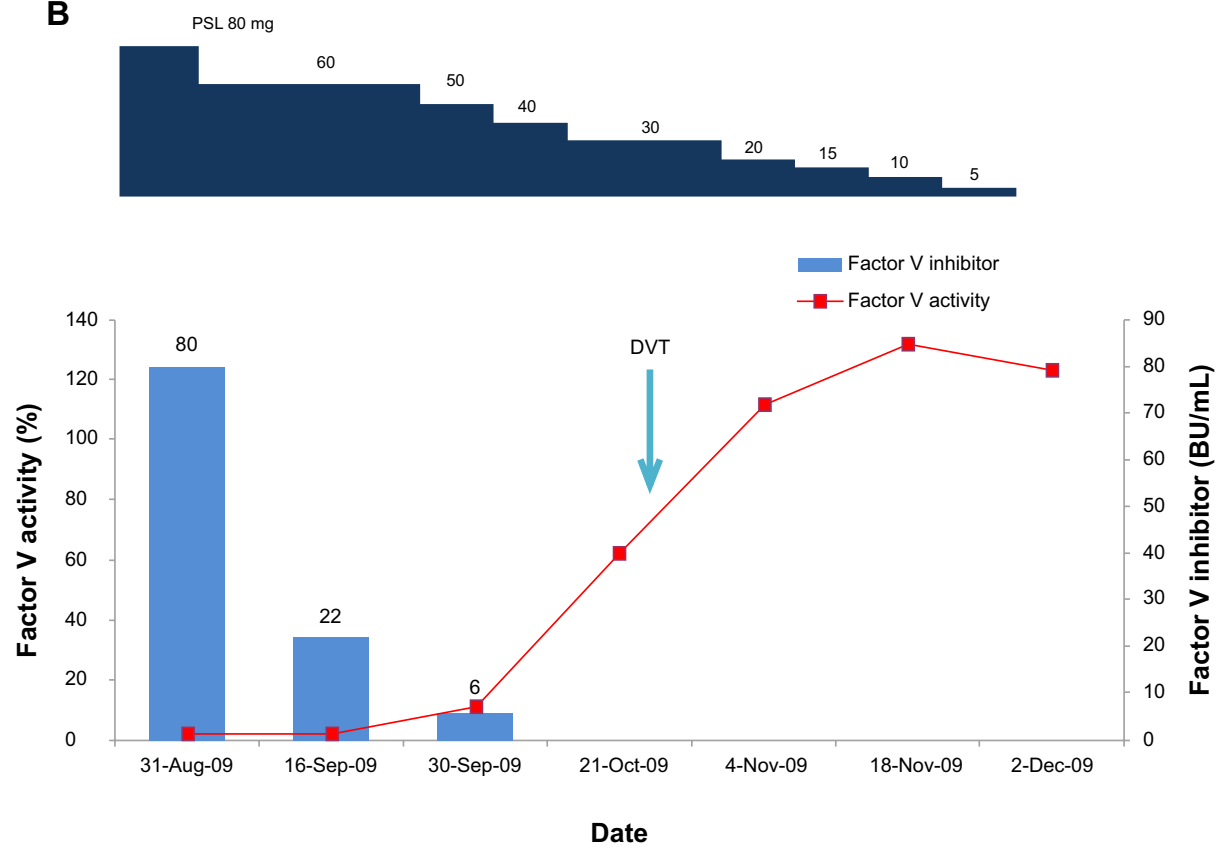

Figure I Clinical course of coagulopathy in a patient with acquired factor V deficiency. (A) Prothrombin time (seconds) and aPTT (seconds) during the course of treatment with PSL for the DVT event marked (arrow). (B) Factor V activity (\%) and circulating levels of inhibitor (BU/mL) during the course of treatment with PSL for the DVT event marked (arrow).

Abbreviations: aPTT, activated partial thromboplastin time; BU, Bethesda units; DVT, deep vein thrombosis; PSL, prednisolone; PT, prothrombin time.

extremely rare..$^{5-9}$ Activated factor $\mathrm{V}$ (FVa) is subsequently inactivated by activated protein C (APC), which cleaves FVa at Arg506, Arg306, and Arg679. After FVa is cleaved at Arg506 (FVac), it further interacts with APC and protein S to enhance the inactivation of activated factor VIII (FVIIIa) by the APS/protein S complex, thereby indirectly acting as an anticoagulant. ${ }^{15,16}$ Factor V inhibitor can hinder this cascade by decreasing the level of FVac, resulting in sustained activation of factor VIII and leading to procoagulant diathesis. Interestingly, an anti-factor $\mathrm{V}$ antibody isolated from a patient 
inhibited the cofactor activity of factor V during the APC/ protein S complex's FVIIIa inactivation cascade by impairing the proper cleavage of FVa by APC and inhibiting the inactivation of FVa. ${ }^{17}$ This confirms that factor $\mathrm{V}$ inhibitors can lead to procoagulant diathesis by both direct and indirect mechanisms. Given that the factor $\mathrm{V}$ inhibitor was undetectable in our patient, it is unlikely that it elicited the development of thrombosis during the course of treatment, but we hypothesize that the significantly elevated factor VIII might have played a role. Additionally, underlying hematological malignancy is another possible provoking factor.

The patient presented in this case report had a unique clinical manifestation of acquired factor $\mathrm{V}$ inhibitor in that thrombosis occurred after factor $\mathrm{V}$ was no longer detectable by an assay measuring Bethesda units; however, the patient still exhibited coagulopathy with high prothrombin time and INR, suggesting the continued presence of a small amount of factor $\mathrm{V}$ inhibitor. At first presentation, his factor VIII level was significantly higher than normal at $3.23 \mathrm{U} / \mathrm{mL}$ (normal $0.5-1.5 \mathrm{U} / \mathrm{mL}$ ) which might have caused this thrombotic event. To our knowledge, this is the first report of acquired factor $\mathrm{V}$ inhibitor in a patient with mantle cell lymphoma simultaneously presenting with this unusual coagulopathy.

\section{Disclosure}

The authors report no conflicts of interest in this work.

\section{References}

1. Tracy P, Eide L, Bowie E, et al. Radioimmunoassay of factor $\mathrm{V}$ in human plasma and platelets. Blood. 1982;60:59-63.

2. Ang A, Kuperan P, $\mathrm{Ng} \mathrm{C}$, et al. Acquired factor V inhibitor. A problem based systematic review. Thromb Haemost. 2009;101:852-859.
3. Favaloro E, Posen J, Ramakrishna R, et al. Factor V inhibitors: rare or not so uncommon? A multi-laboratory investigation. Blood Coagul Fibrinolysis. 2004;15:637-647.

4. Horder M. Isolated factor V deficiency caused by a specific inhibitor. Acta Haematol. 1955;13:235-241.

5. Kapur A, Kelsey P, Isaacs P. Factor V inhibitor in thrombosis. Am J Hematol. 1993;42:384-388.

6. Koyama T, Saito T, Kusano T, et al. Factor V inhibitor associated with Sjögren's syndrome. Br J Haematol. 1995;89:893-896.

7. George S, Nagabhushana M, Cyran E. Coagulopathy due to an acquired factor V inhibitor and subsequent thrombosis. Am J Hematol. 1995;49: 98-100.

8. Kamphuisen P, Haan J, Rosekrans P, et al. Deep-vein thrombosis and coumarin skin necrosis associated with a factor $\mathrm{V}$ inhibitor with lupus-like features. Am J Hematol. 1998;57:176-178.

9. Higuchi T, Okamoto T, Kou T, et al. Deep vein thrombosis associated with factor V inhibitor followed by immune thrombocytopenia. Ann Hematol. 2012;91:1831-1832.

10. Minoo A, Nader R. Acquired factor V inhibitor developing in a patient with esophageal squamous cell carcinoma. Blood Coagul Fibrinolysis. 2013;24:97-99.

11. Franchini M, Lippi G. Acquired factor V inhibitors: a systematic review. J Thromb Thrombolysis. 2011;31:449-457.

12. Shreenivas AV, Lipshitz J, Patel D. A rare case of factor V inhibitor in a patient on amiodarone therapy. Blood Coagul Fibrinolysis. 2012;23:342-344.

13. Gartrell B. Acquired factor $\mathrm{V}$ inhibitor complicating warfarin therapy. Am J Hematol. 2011;86:710-712.

14. Streiff M, Ness P. Acquired FV inhibitors: a needless iatrogenic complication of bovine thrombin exposure. Transfusion. 2002;42: $18-26$.

15. Shen L, Dahlbäck B. Factor V and protein $\mathrm{S}$ as synergistic cofactors to activated protein $\mathrm{C}$ in degradation of factor VIIIa. J Biol Chem. 1994;269:18735-18738.

16. Duckers C, Simioni P, Rosing J, et al. Advances in understanding the bleeding diathesis in factor V deficiency. Br J Haematol. 2009;146: $17-26$.

17. Kalafatis M, Simioni P, Tormene D, et al. Isolation and characterization of an antifactor $\mathrm{V}$ antibody causing activated protein $\mathrm{C}$ resistance from a patient with severe thrombotic manifestations. Blood. 2002;99: 3985-3992.
International Medical Case Reports Journal

\section{Publish your work in this journal}

The International Medical Case Reports Journal is an international, peer-reviewed open-access journal publishing original case reports from all medical specialties. Previously unpublished medical posters are also accepted relating to any area of clinical or preclinical science. Submissions should not normally exceed 2,000 words or

\section{Dovepress}

4 published pages including figures, diagrams and references. The manuscript management system is completely online and includes a very quick and fair peer-review system, which is all easy to use. Visit $\mathrm{http}: / /$ www.dovepress.com/testimonials.php to read real quotes from published authors. 